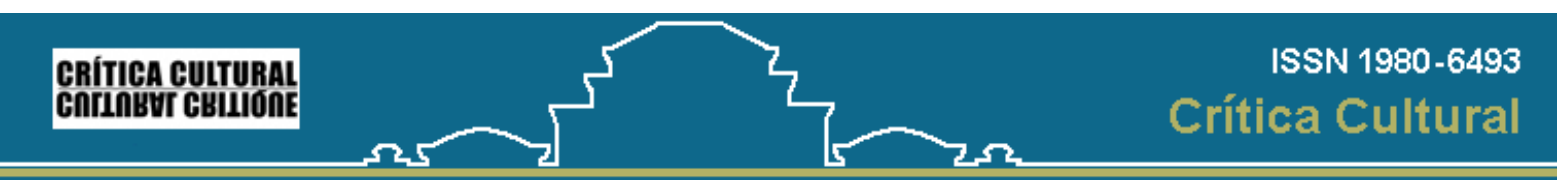

Crítica Cultural, volume 2, número 1, jul./dez. 2007

\title{
A FABRICAÇÃO DE UMA CONVIVÊNCIA
}

\author{
Renata Telles* $^{*}$
}

Resumo: Leitura da narrativa Nove Noites, de Bernardo Carvalho, e da crítica que Graciliano Ramos faz ao filme Descobrimento do Brasil, de Humberto Mauro, permitem a autora desenhar as relações entre Estado, arte e intelectuais nos 30, entre cultura e sociedade, entre tempo e história, passado e presente, história e literatura com o objetivo de ensaiar uma política da memória e das gerações que não apague a diferença, mas que busque manter e provocar uma convivência tensa entre presente e passado, entre real e possível.

Palavras-chave: literatura, teoria literária, cultura.

Todo o que eu queria saber já era conhecido. E ele me perguntava: "Então, por que você quer saber, se já sabe?" Tentei lhe explicar que pretendia escrever um livro e mais uma vez o que era um romance, o que era um livro de ficção (e mostrava o que tinha nas mãos), que seria tudo historinha, sem nenhuma conseqüência na realidade.

Bernardo de Carvalho

Entre o ainda não e o nunca, Nove noites. Na certeza de um leitor futuro, um pronome pessoal sempre aguardado, escreve-se um relato, uma carta, um testamento, aquilo que permite a sobrevivência da memória e a continuidade da incógnita. Na ausência de um interlocutor passado, um pronome indefinido nunca presente, articulam-se fragmentos, reviram-se arquivos e lembranças em busca de respostas que nunca foram dadas a perguntas que nunca ninguém fez. Responder ao futuro e perguntar ao passado.

Isto é para quando você vier. É preciso estar preparado. Alguém terá de preveni-lo. Vai entrar numa terra em que a verdade e a mentira não têm mais os sentidos que o trouxeram até aqui. Pergunte aos índios. Qualquer coisa. O que primeiro the passar pela cabeça. E amanhã, ao acordar, faça de novo a mesma pergunta. E depois de amanhã, mais uma vez. Sempre a mesma pergunta. E a cada dia receberá uma resposta diferente. A verdade está perdida entre todas as contradições e os disparates. Quando vier à procura do que o passado enterrou, é preciso saber que estará às portas de uma terra em que a memória não pode ser exumada, pois o segredo, sendo o único bem que se leva para o túmulo, é também a única herança que se deixa aos que ficam, como você e eu, à espera de um sentido, nem que seja pela suposição do mistério, para acabar morrendo de curiosidade. (CARVALHO, 2002, p.7)

Ninguém nunca me perguntou. E por isso também nunca precisei responder. Não posso dizer que nunca tivesse ouvido falar nele, mas a verdade é que não fazia a menor idéia de quem ele era até ler o nome de Buell Quain pela primeira vez num artigo de jornal, na manhã de 12 de maio de 2001, um sábado, quase sessenta e dois anos depois de sua morte às vésperas da Segunda Guerra. O artigo saiu meses antes de outra guerra ser deflagrada. Hoje as guerras parecem mais pontuais, quando no fundo são permanentes (p.17)

Entre a carta-testamento que passa adiante o segredo e a investigação que supõe o mistério, está Buell Quain, o jovem antropólogo americano, que, em 1939, se suicida na selva brasileira entre os índios Krahô. A espera de um sentido, supondo o mistério e alimentando a curiosidade que faz viver e que termina por matar, dois narradores circulam entre 1939 e 2001, entrelaçando biografias pessoais e coletivas. É preciso preveni-lo. Exumar a memória significa entrar numa terra em que a verdade e a mentira perderam o sentido, numa terra de contradições e disparates. É preciso estar preparado. Desenterrar o passado significa buscar mais uma resposta para a mesma pergunta, transitar numa zona de indiferenciação entre o real e o imaginário, entre o verídico e o verossímil, suportando o insuportável: a idéia de que a verdade nunca é acessível.

A cada repetição da pergunta, uma resposta diferente. Um movimento circular sempre incompleto, que pede sempre mais uma volta. A mesma pergunta, sempre igual, e a resposta nunca a mesma, sempre diferente, definem uma maneira de conceber o tempo e narrar a história. 0 relato de um certo passado é uma certa resposta do presente que se soma a outras respostas que já foram dadas à pergunta que se repete há muito tempo. Na simultaneidade de respostas contraditórias, na sobreposição de tempos, memórias e documentos, na alternância de narradores e de narrativas, Nove noites responde à pergunta com (auto)biografias, maneiras de ler e de escrever que nos falam sobre eles e sobre nós, sobre a literatura e o tempo.

Seja bem-vindo. Vão Ihe dizer que tudo foi muito abrupto e inesperado. Que o suicídio pegou todo mundo de surpresa. Vão lhe dizer muitas coisas. Sei o que espera de mim. E o que deve estar pensando. Mas não me peça o que nunca me deram, o preto no branco, a hora certa. Terá que contar apenas com o imponderável e a precariedade do que agora lhe conto, assim como tive que contar com o relato dos índios e a incerteza das traduções do professor Pessoa. As histórias dependem antes de tudo da confiança de quem as ouve, e da capacidade de interpretá-las.(p.8)

Os papéis estão espalhados em arquivos no Brasil e nos Estados Unidos. Fiz algumas viagens, alguns contatos, $e$ aos poucos fui montando um quebra-cabeças e criando a imagem de quem eu procurava. Muita gente me ajudou. Nada dependeu de mim, mas de uma combinação de acasos e esforços que teve início no dia em que li, para o meu espanto, o artigo da antropóloga no jornal e, ao pronunciar aquele nome em voz alta, ouvi-o pela primeira vez na minha própria voz.(p.14)

Uma carta em primeira pessoa que fala de uma terceira, que narra uma convivência, para um destinatário desconhecido e singular. Uma narrativa de lembranças, as de Manoel Perna e as de Quain, que Ihe contara histórias do seu passado em outros lugares. Um humilde e educado sertanejo amigo dos índios escuta o pesquisador norte americano angustiado e interessado nos mesmos índios, durante nove noites em Carolina, na fronteira do Maranhão com o Tocantins, onde permanece cinco meses. Eu, ele, eles. 0 sertanejo, o aluno predileto de Franz Boas, os índios brasileiros. América do Norte e América do Sul. Seis anos depois do suicídio de Buell Quain, no final do Estado Novo e da guerra, Manoel Perna, pouco tempo antes da sua morte em 1946, deixa um testamento para um destinatário aguardado desde 1939, desde a véspera da guerra. 0 passado (a)guardado para o futuro. Isto é para quando você vier.

Uma narrativa em primeira pessoa que fala de uma terceira para um leitor anônimo e múltiplo. A re-construção da vida de um desconhecido, a fabricação de uma convivência que nunca existiu com o que não mais existe. Um quebra-cabeça cujas peças são formadas por relatos de terceiros, memórias de outros que reacendem as suas, fatos e documentos arquivados, uma montagem presidida pela suposição, pela oportunidade e pelo acaso. Sessenta e dois anos depois do suicídio de Buell Quain, pouco antes da eleição de um sindicalista para a presidência, um jornalista fica fascinado com a informação e desencadeia uma investigação nos dois países, Brasil e Estados Unidos, Tocantins e Rio de Janeiro, na véspera de outra guerra. 0 passado (a)guardado no presente. Ninguém nunca me perguntou.

As histórias dependem da confiança de quem as ouve. Saber escutar o outro. Durante nove noites Manoel Perna escuta 
incansavelmente Buell Quain. Acompanha com interesse as lembranças fragmentárias e atormentadas que o levam a Minesotta, Nova York, I lhas do Pacífico, Rio de Janeiro, Xingu. Ao paraíso e ao inferno, enquanto Manoel Perna escuta e imagina "o seu sonho e o seu pesadelo". O ouvinte privilegiado escreve a vida de Buell Quain para um ouvinte que virá. As histórias dependem da capacidade de interpretá-las.

Saber escutar o outro na própria voz. Ao ouvir Buell Quain o jornalista escuta Bill Cohen. O som do outro na própria voz o faz lembrar que ele fora confundido com o antropólogo por um velho americano, que escutava leituras de Melville e Conrad, no quarto de hospital em São Paulo. A reconstrução, sessenta e dois anos depois, da vida de quem não mais existe é também o relato de uma escuta. 0 som do nome do outro ecoa na memória. Buell Quain e Bill Cohen estabelecem a convivência que não aconteceu. A repetição do som leva o narrador de volta ao pai moribundo no mesmo quarto de hospital, em 1990, e às fazendas que o pai possuía na região do Xingu, na época da ditadura militar. 0 leva de volta mais uma vez à mesma região, dessa vez em 2001, para escutar um velho índio repetir o nome, cujo significado ninguém sabia ao certo. Cãm - twýon: a lesma, o caracol e seu rastro - o presente, 0 aqui e agora.

O antropólogo me explicou que, ao contrário do que costumam pensar os brancos, os nomes dos índios nem sempre querem dizer alguma coisa e sobretudo nada têm a ver com a personalidade da pessoa nomeada. Fazem parte de um repertório e são atribuídos ao acaso. Eu teria que voltar para São Paulo sem saber o que significava aquele nome. Mas não conseguia aceitar que não revelasse alguma coisa sobre o próprio Quain, que não houvesse nenhuma relação entre o nome e a pessoa. Decidi-me por uma interpretação selvagem e um tanto moral: "Cãmtwýon" passou a ser, para mim, ao mesmo tempo a casa do caracol e seu fardo no mundo, a casca que ele carrega onde quer que esteja e que também lhe serve de abrigo, o próprio corpo, do qual não pode se livrar a não ser com a morte, o seu aqui e agora para sempre. "Cãmtwýon" passou a ser para mim o rastro do caracol: não adianta fugir, aonde quer que você vá estará sempre aqui.(p.80/81)

2001 - 1939 - 1967. Nova York - Rio de Janeiro - Xingu. Universidade - Estado - Índios. Não adianta fugir, estará sempre aqui. 0 morto está vivo. É preciso falar com ele e sobre ele é preciso se dirigir aos espectros que nos rondam. Os narradores falam para o presente e para o futuro e dizem "eu" no passado: eu vi, eu ouvi, eu li, eu entrevistei, eu encontrei. Narram a vida do morto, vivo na memória. Na fronteira do presente e do passado, do eu e do outro, da vida e da morte, os narradores se dirigem aos fantasmas para aprender a viver.

É preciso saber escutar, confiar e interpretar. $O$ antropólogo, morto na véspera da guerra e no auge do Estado Novo, se dedicava à descrição das relações de parentesco e da língua, em vias de extinção, dos Krahô. Era aluno de Franz Boas, que alguns anos antes já fascinara Gilberto Freyre na Columbia University. Buell Quain não conhece o autor de Casa Grande \& Senzala, nem no Brasil nem em Nova York, mas no interior do Mato Grosso, em um hotel de um lugarejo inóspito, conhece Lévi-Strauss, o estudioso dos Nhambiquara que viera poucos anos antes para a recém-criada Universidade do Estado de São Paulo. Em 1940, um ano depois do suicídio do jovem americano, o antropólogo judeufrancês, depois de ter o visto brasileiro recusado pelo Estado Novo, chega a Nova York, onde conhece Boas e Jakobson, e logo depois publica As estruturas elementares do parentesco, leitura fundamental dos teóricos estruturalistas que despontam nos anos 60 na França, no mesmo momento em que o jornalista brasileiro, então criança, é apresentado, pelo pai, aos índios do Xingu.

Odeio as viagens e os exploradores. E eis que me preparo para contar minhas expedições. Mas quanto tempo para me decidir! Quinze anos passaram desde que deixei o Brasil pela última vez, e, durante todos esses anos, muitas vezes planejei iniciar este livro; toda vez, uma espécie de vergonha e repulsa me impediram. E então? Há que narrar minuciosamente tantos pormenores insípidos, acontecimentos insignificantes? Não há lugar para a aventura na profissão de etnógrafo; ela é somente a sua servidão, pesa sobre o trabalho eficaz com o peso das semanas ou dos meses perdidos no caminho; das horas improdutivas enquanto o informante se esquiva; da fome, do cansaço, às vezes da doença; e, sempre, dessas mil tarefas penosas que corroem os dias em vão e reduzem a vida perigosa no coração da floresta virgem a uma imitação do serviço militar. (LÉVI-STRAUSS,1996, p.15).

A repulsa e a vergonha em relatar a tarefa penosa a que se obriga o europeu moderno ao conviver com aquilo que a modernidade se esforça em deixar para trás, o improdutivo e o esquivo que corroem o tempo, a servidão, a fome e a doença, no desejo de se conhecer através do outro, leva por um lado à construção de invariáveis universais que problematizam a distância e a diferença, e por outro lado, à reafirmação dessa distância e dessa diferença pelo universitário americano que não é, e não suporta ser, o outro. Para viver com esses dois lados, Buell Quain adota duas caras, que se revelam nas cartas que escreve a uma amiga brasileira relatando como ficara "impressionado pelo sério interesse da audiência", e à orientadora americana revelando que "Carolina é um lugar tedioso - analfabetos e intelectuais".

Enquanto os dois pesquisadores estrangeiros se equilibram entre a honestidade e a falsidade, entre o céu e o inferno, durante o Estado Novo, o jornalista paulista define a sua aversão na infância e assume, sem álibi, a culpa na vida adulta. Depois do massacre da colonização, da "guerra justa" de D. João, da política de "pacificação" e "atração" do Serviço de Proteção aos Índios, chefiado pelo Marechal Rondon, avô do narrador, é durante o avanço e a ocupação patrocinada pela ditadura militar, e sob a recém-criada Funai, que o então menino é apresentado pelo pai à selva e aos índios, e é durante a conflituosa demarcação das terras indígenas e de áreas de preservação ambiental patrocinada pela democracia civil e liberal, que o jornalista, acompanhado de uma ONG, retorna ao mesmo lugar.

Ele articulava desde 1966, em Brasília, a compra de dois latifúndios no sertão, por meio de títulos definitivos do governo. Era um negócio da China. Não só pagou uma ninharia pelas terras, como passou a receber subsídios para o projeto agropecuário que implantou a partir de 1970. A prática foi estabelecida como programa pelo governo militar, que sob o pretexto do desenvolvimento da Amazônia não só subvencionou a compra de centenas de milhares de alqueire a preço de banana, como em seguida financiou nababescamente os projetos de ocupação pelos fazendeiros - em geral, bastava derrubar a mata, plantar capim e encher as fazendas de gado. (p.65)

O Xingu, em todo caso, ficou guardado na minha memória como a imagem do inferno. Não entendia o que dera na cabeça dos índios para se instalarem lá, o que me parecia de uma burrice incrível, se não um masoquismo e mesmo uma espécie de suicídio. Não pensei mais no assunto até o antropólogo que por fim me levou aos krahô, em agosto de 2001, me esclarecer: Veja o Xingu. Por que os índios estão lá? Porque foram sendo empurrados, encurralados, foram fugindo até se estabelecerem no lugar mais inóspito e inacessível, o mais terrível para a sua sobrevivência, e ao mesmo tempo a sua única e última condição. O Xingu foi o que lhes restou." (p.73)

Antes de sair da aldeia, diante da minha recusa em ser batizado, Gersila se aproximou de mim, entre ofendida e irônica, e me jogou na cara que eu era como todos os brancos, que os abandonaria, nunca mais voltaria à aldeia, nunca mais pensaria neles. Jurei que não. Estava apavorado com o que pudessem fazer comigo (além de me cobrir de penas e me dar um nome e uma família da qual nunca mais poderia me desvencilhar). 0 meu medo era visível. Fiz um papel pífio. E eles riram da minha covardia. Jurei que não me esqueceria deles. E os abandonei, como todos os brancos. (p.109)

Da vida de um terceiro no final dos anos 30, reconstituída em uma carta pessoal de um sertanejo em 1946 e em um romance público de um escritor urbano em 2001, emerge a vida dos dois narradores. Nove noites entrelaça tempos e espaço, personagens e narradores, documento e ficção na tentativa de responder de outra forma à pergunta que é sempre a mesma: entre a colonização e a globalização, entre 0 sul e 0 norte, entre a metrópole e a selva, entre a universidade e o estado, entre o presente e o passado, entre a civilização e a barbárie, como escrever "eu"?

O momento decisivo da vida e da morte de Buell Quain e da carreira de Claude Lévi-Strauss entre as culturas amazônicas é também o momento forte de Getúlio Vargas, o ditador que permite e controla o movimento dos pesquisadores estrangeiros entre os índios brasileiros. A submissão às regras, as artimanhas para driblá-las e o não-questionamento das condições locais marcam as delicadas relações de compromisso entre professores estrangeiros, universidades brasileiras, estado e polícia. O Departamento de Antropologia da Columbia University, dirigido por Franz Boas, no qual também atuava Ruth Benedict, orientadora de Buell Quain, firma um acordo com o Museu Nacional do Rio de Janeiro, dirigido por Heloísa Alberto Torres, que "soube manter a sua influência e assegurar o seu cargo durante todo o Estado Novo", sendo a responsável pelos jovens antropólogos americanos.

A prostação de Quain se devia em especial às dificuldades que enfrentava para chegar ao Xingu sem as devidas A prosizãões. Sua expediç̃o solitária a Trumai terminaria com uma convocação expressa de volta a Rio de autorizações. Sua expedição solitária aos Trumai terminaria com uma convocação expressa de volta ao Rio de
janeiro nos seguintes termos: "De conformidade com a recomendação do Senhor Tenente-Coronel Vicente de Paulo Teixeira da Fonseca Vasconcelos, Chefe do Serviço de Proteção aos Índios, venho, por este meio, vos convidar para retirardes da aldeia dos índios trumai onde vos encontrais, visto como a vossa permanência ali constituiu infração ao regulamento daquele Serviço. Saúde e fraternidade, Álvaro Duarte Monteiro, Inspetor 
Regional do Ministério do Trabalho, interino". Em carta a Ruth Benedict, Heloísa Alberto Torres se explica: "Certos equívocos por parte do Sr. Quain foram interpretados pelo Serviço como infrações à lei e levaram este órgão a impor-Ihe condições estritas se ele desejar prosseguir com suas pesquisas nas aldeias indígenas". Castro Faria diz que essa era a praxe: "Até eu, que era membro-delegado do Conselho de Fiscalização na expedição do Lévi-Strauss, precisava de um salvo-conduto". (p.44)

Os pesquisadores estrangeiros desenvolvem seu trabalho junto aos índios intocados pela civilização moderna graças às artimanhas $e$ ao pacto com a ditadura de direita, que nesse momento se expande e se consolida. A combinação de centralização, modernização e nacionalismo implantada pelo governo de Vargas desenha, por um lado, um estado autoritário e autônomo, acima da classe e do indivíduo, que passa por uma racionalização do serviço público e pela proliferação de aparelhos estatais, conselhos, comissões, autarquias, institutos, sindicatos, que organizam a economia, a saúde, o trabalho, a comunicação, a educação, a cultura. Por outro lado, a autonomia totalitária funde Estado e Nação na figura de Getúlio Vargas, numa mistura de civismo e culto à personalidade montada pela máquina de propaganda do Estado. A arte moderna e autônoma e o Estado moderno e autônomo fundem-se no Ministério da Educação e Cultura, no Departamento de Imprensa e Propaganda, no Serviço do Patrimônio Histórico e Artístico Nacional, no Instituto Nacional do Livro, no Instituto Nacional do Cinema Educativo, na Rádio Nacional, na Superintendência de Educação Musical e Artística do Distrito Federal.

Além de todas essas relações abertas pela leitura de Nove noites, podemos lembrar também que enquanto o Conselho Nacional do Índio vigia os antropólogos estrangeiros, que pesquisam as estruturas de parentesco sob a responsabilidade do Museu Nacional do Rio de Janeiro, assiste-se nas salas de cinema uma "realização cívico-cultural" do Instituto do Cacau da Bahia, sob a direção do principal cineasta do Instituto Nacional do Cinema Educativo, Humberto Mauro, com a "colaboração intelectual e a verificação histórica" de Affonso de Taunay, Bernardino José de Souza e Edgar Roquette Pinto, diretor do INCE, e música, com a Grande Orquestra Sinfônica e 100 vozes do Orfeão de professores do Distrito Federal, de Heitor Villa-Lobos, superintendente de Educação Musical e Artística do Distrito Federal. Com duração de 62 minutos, o documentário tem como roteiro a carta de Pero Vaz de Caminha e reconstitui a viagem de Pedro Álvares Cabral, da partida do Tejo à primeira missa no Brasil, misturando cenas externas e internas, cartelas de legendas com trechos da carta e animações que representam o percurso das naus.

Tendo sido preso pela ditadura no ano anterior, em 1937, já livre, o autor de Memórias do cárcere, nomeado em 1939 Inspetor de Ensino Federal e em 1941 funcionário do Departamento de Imprensa e Propaganda, escreve sobre $O$ descobrimento do Brasil uma rara crítica de cinema: "Uma tradução de Pero Vaz".

Dividido entre o gosto e o desgosto, Graciliano organiza a sua crítica em duas partes. Na primeira, exalta o financiamento estatal, se assombra com a qualidade técnica e declara o filme um divisor de águas no cinema nacional: os espectadores patriotas, que antes viam películas chochas por obrigação, agora podem ver trabalhos sérios e decentes por gosto. $O$ descobrimento do Brasil faz a diferença porque reproduz um texto em figuras, entre as quais se destacam as cenas da multidão, composta de fidalgos em seda, marujos descalços e índios dançantes, ao som de Villa-Lobos. Se as admiráveis cenas reproduzem com perfeição os diferentes personagens sociais da carta de Pero Vaz, o crítico chama atenção ainda para o fato de que o filme conta apenas com três atores profissionais, destacando a atuação de um peixeiro, que chega a incorporar o personagem fora da tela, e a veracidade dos índios.

Ao contrário dos selvagens ingênuos, confiáveis e excitáveis, cuja representação é perfeita, na segunda parte da crítica Graciliano revela todo o seu desgosto e seu espanto com a representação dos estrangeiros, receptivos e hospitaleiros. Embora essa seja uma tradução fiel, há uma diferença entre a carta e o filme, entre contar e mostrar: a visibilidade dos pormenores prejudica a verossimilhança.

Uma coisa é ler "cobriram-nos com um manto e eles o consentiram". Outra coisa é ver, no escuro do cinema, a expressão de beatitude e delicadeza, de maternidade e solicitude. Outra coisa é ver, nas imagens de luz, a baba condescendente que acompanha o gesto do invasor, sabendo, em 1937, o que os portugueses fizeram em seqüência, na África, na Ásia e na América. 0 pormenor que prejudica a verossimilhança o conhecimento da história. Se o gosto de Graciliano é ver a reprodução das figuras da carta, o seu desgosto é ver, no melhor filme brasileiro, retratos desfigurados pela intenção de melhorar a imagem do invasor.

A mesma intenção pedagógica e o mesmo gesto autoritário comandam tanto a ditadura de direita que desfigura a verdade para impor a imagem de uma colonização pacífica e amistosa, quanto a arte de esquerda que figura a verdade para impor a imagem de uma colonização hostil e conflituosa: congelar uma imagem, unificar as histórias, singularizar a nação autônoma. Se Graciliano se opõe à delicadeza que a história oficial empresta ao português e a contrapõe à virilidade, à aventura e ao interesse dos terríveis exploradores, ele preserva a ingenuidade, confiança e a pureza que a história nacional reservou aos índios desde a independência. 0 nativo que se aproxima do estrangeiro sem malícia e confiante, que cospe o que não gosta e que dorme quando tem sono, o homem que desconhece as convenções e falsidades da sociedade civilizada, é muito verdadeiro, perfeito. A pequena crítica de Graciliano ao filme de Humberto Mauro baseado na carta de Pero Vaz Caminha arma uma série interminável de oposições duais: verossímil $x$ verídico, acréscimo $x$ fato, imagem $x$ texto, delicadeza $x$ virilidade, hospitalidade $x$ assassinato, história oficial $\mathrm{x}$ história dos vencidos, social $\mathrm{x}$ natural.

Diante da multiplicidade de duplos, a escolha inequívoca do crítico sempre deixa um resto. Ao optar pelo verídico, pelo texto que relata um fato sem acréscimos, pela imagem real, e ao condenar, afastar e discriminar o inverossímil, a representação que excede o fato, a imagem falsa, o escritor, sob a ditadura, constrói a história de uma nação viril, cuja origem não é a delicadeza e o pacifismo, mas o conflito, a guerra, a exploração e o assassinato. Ao mesmo tempo em que denuncia a força e a violência dos primeiros modernos como um dado negativo, diferenciando-a da ingenuidade natural dos índios como um dado positivo, o crítico defende a sua verdade com a mesma força e violência dos invasores europeus e da ditadura, excluindo a possibilidade de convivência, hierarquizando valorativamente os opostos, organizando a história que vai do natural ao político, da origem ao presente. Graciliano é um moderno com saudades de um primitivo que nunca conheceu e que se

contrapõe ao presente do qual faz parte.

O romance publicado em 2002 e a crítica de cinema que circula em 1937 nos falam sobre o tempo e a história, a cultura e a sociedade, o passado e o presente, nos falam sobre a vida, a deles e a dos outros, a nossa. Nove noites escreve, a partir do fim, a vida de um antropólogo americano que viveu com os índios durante o Estado Novo; escreve também a vida do narrador-pesquisador e de seus contatos com os índios, mediados pelo pai e pelas ONGs, durante a ditadura militar e a democracia; escreve ainda a vida do narrador-testemunho da carta, que viveu entre os índios e o americano. "Uma tradução de Pero Vaz" escreve, a partir do fim, a vida, a sua e a da nação, resultante do contato entre o europeu e o índio, relendo, durante o Estado Novo, a descrição inaugural desse contato na carta em primeira pessoa enviada ao Rei D. Manuel, em 1500

As autobiografias, segundo Sylvia Molloy, sempre apontam para a mesma pergunta: Quem sou "eu"? (MOLLOY, 2003) A pergunta, já nos avisara Nove Noites, é sempre a mesma, assim como o percurso dos viajantes que, segundo Georges Gusdorf, retornam sempre ao ponto de partida.

0 viajante, concluído seu grande tour, retorna ao ponto de partida; ele percebe então que sua exploração, sob o pretexto aparente da procura de terras novas, tinha como intenção secreta a descoberta de si, enriquecida das aquisições saqueadas ao longo do caminho, que the permitiram perceber no espelho do mundo aspectos insuspeitados de sua personalidade. (GUSDORF, 1991, p.8)

Se a carta de Pero Vaz, nosso ponto de partida oficial, pode ser lida como uma autobiografia, como uma autofiguração a partir do outro, anunciando Dos Canibais de Montaigne e A Tempestade de Shakespeare, por exemplo, há que se resguardar certas diferenças para as quais Sylvia Molloy chama a atenção. 0 relato do viajante seria uma forma remota que tangencia a autobiografia, uma escrita na qual o "eu" não é o objeto, nem a finalidade, apenas o meio e o efeito, em função de uma circunstância que o limita: o Rei como destinatário que tem poder sobre 0 autor e 0 texto.(MOLLOY, 2003, p.15) Se tal definição problematiza a leitura da carta como uma autobiografia, D. Manuel e Getúlio Vargas aproximam Pero Vaz e Graciliano Ramos, dois narradores sob o poder, de prisão e de emprego, do Rei e do Ditador.

Ao rever a carta no filme que a traduz em imagens, Graciliano retorna ao ponto de partida e aponta para a mesma pergunta, ensaiando uma resposta diferente. Enquanto Pero Vaz relata um primeiro contato amistoso e cuidadoso para o rei absolutista, enquanto Humberto Mauro retrata um cuidado materno e uma delicadeza na descoberta inaugural do outro para o ditador moderno, Graciliano, contra relato estatal, mas a favor da pedagogia, escreve a força e a brutalidade dos invasores como a verdade do contato com o outro, de tal forma que o passado confirma uma auto-imagem sustentada no presente.

A autobiografia é sempre uma re-presentação, ou seja, um tornar a contar, pois a vida a que supostamente se refere é, por si mesma, uma construção narrativa. A vida é sempre, necessariamente, uma história; história que contamos a nós mesmos como sujeitos, através da rememoração; ouvimos sua narração ou a lemos quando a vida não é nossa. Portanto, dizer que a autobiografia é o mais referencial dos gêneros - entendendo por referência o remeter ingênuo a uma "realidade" e a fatos concretos, verificáveis - é, em certo sentido, pôr a questão de maneira falsa. A autobiografia não depende de acontecimentos, mas da articulação destes eventos armazenados na memória e reproduzidos através da rememoração e verbalização. (MOLLOY, 2003, p.19)

As respostas sempre diferentes encenam um diálogo entre maneiras de narrar a história e a literatura. De um lado, os acontecimentos desmentem a arte pois "sabemos que foi diferente". O narrador dá forma a uma verdade já formada e o leitor lhe delega o poder de guiá-lo a um final. De outro lado, a arte articula memórias e acontecimentos e diz que é "tudo inventado", para "os que ficam, como você e eu, à espera 
de sentido". Diversos narradores reconfiguram uma verdade nunca formada e deixam o leitor à deriva. A pergunta sempre a mesma, a resposta sempre diferente. "Uma tradução de Pero Vaz" apela para o documentado e acontecido, afasta o excesso e o inverossímil que vê em 0 descobrimento do Brasil, na tentativa de unificar a escrita da vida nacional e domesticar a memória. Declarada a morte do Rei, do Estado Nacional e do pai, Nove noites não tem mais um destinatário todo poderoso a quem se dirigir e se submeter, não tem mais um único narrado que organiza e assegura o desenrolar da história, não atesta mais a sua veracidade nos acontecimentos passados. Nove noites responde a mesma pergunta escutando e dando voz ao outro, seja ele o índio do Tocantins ou o antropólogo de Columbia, o sertanejo ou a diretora do Museu Nacional, recorrendo a arquivos públicos e a correspondências privadas, entrelaçando vidas e tempos, mergulhando na memória e na rememoração, tratando a forma como conteúdo.

A função da noção de autobiografia aqui não é a de marcar a constância de uma forma ou comprovar a rigidez de uma classificação, mas, muito pelo contrário, a de permitir a construção de relações seletivas e eletivas de parentesco entre os não-idênticos, textos diversos e díspares, romance e crítica de cinema, e a de permitir o trânsito anacrônico entre tempos distantes e próximos, que em 1937 nos leva a 1500 e em 2001 nos leva a 1939 e 1967, nos quais a tensão entre o eu e o outro produz faísca. Não se trata ainda de perseguir a evolução e a transformação de um gênero textual de 1500 a 2001, da carta do viajante ao romance fragmentário e descontínuo, mas, muito pelo contrário, o interesse é marcar, pela constância da pergunta e pela divergência das respostas, pela permanência da tradição e pelo desvio da diferença, a permanência de um problema: a relação entre literatura, política e tempo.

Essas autobiografias coletivas contam uma história do espaço e do tempo. O contato do detentor da escrita e da imprensa (que conferem à obra uma duração maior do que a existência do homem, fazendo do passado objeto de conhecimento e do presente, legado para o futuro), da moeda (que torna comparável e comensurável o distinto) e do relógio (que desvincula o tempo de um suporte natural), com o índio selvagem e natural insere o espaço americano no globo geográfico moderno e na temporalidade contemporânea.

O romance e a crítica de cinema nos levam do descobrimento ao Estado Novo, do governo militar ao governo civil, do território ocupado ao estado nacional centralizado, da ditadura à democracia, da nação à pós-nação, das navegações à globalização, sob a guerra permanente. Do massacre à pacificação, da expulsão à demarcação, os conquistadores, os estudiosos das universidades, o estado, 0 exército, as organizações não-governamentais e os escritores se defrontam com o outro: o pré-moderno que resiste à sincronização e sobrevive à modernização. Sob o estado totalitário, centralizador e modernizador dos anos 30, sob a sangrenta guerra mundial, no momento em que 0 mundo passa a ser outro e em que a dimensão da desilusão começa a ser constatada, o pesquisador estrangeiro e 0 escritor nacional, 0 estruturalismo e o marxismo, ensaiam respostas sobre o tempo, tendo o índio como objeto e o Brasil como cenário.

Buscando estruturas universais e sincrônicas, Lévi-Strauss marca a diferença entre a etnografia e a história, embora ambas se interessem por "sociedades que são outras que não aquela onde vivemos".

Assim, a etnologia não pode permanecer indiferente aos processos históricos e às expressões mais altamente conscientes dos fenômenos sociais. Mas se ela lhes dá a mesma atenção apaixonada que o historiador, é para chegar, por uma espécie de marcha regressiva, a eliminar tudo o que devem ao acontecimento e à reflexão. Sua finalidade é atingir, além da imagem consciente e sempre diferente que o homem forma de seu devir, um inventário de possibilidades inconscientes, que não existem em número ilimitado; e cujo repertório e as relações de compatibilidade ou de incompatibilidade que cada uma mantém com todas as outras fornecem uma arquitetura lógica a desenvolvimento históricos que podem ser imprevisíveis, sem nunca ser arbitrários. (LÉVISTRAUSS, 1975, p.39)

Enquanto o europeu, que sente vergonha e repulsa em relatar os pormenores insípidos em sua autobiografia entre os índios durante 0 Estado Novo, descarta a idéia de raça, evolução e progresso, para conceber as relações entre as diversas culturas como um jogo combinatório de afastamentos diferenciais, o escritor brasileiro, que passou pelo cárcere do governo que defende a raça, a evolução e o progresso, concebe a relação entre as diversas culturas como uma guerra. A história da nação deve ser narrada como uma luta de forças desiguais, e obviamente valorativas, entre o índio e o português, o antigo e o moderno, o natural e o industrial, a ingenuidade e a exploração. A história deve contar que o presente, a força que ganhou a guerra, é resultado da brutalidade com a qual ele excluiu a força que perdeu a guerra, o passado. 0 presente tem a tarefa de resgatar essa verdade do passado e colocar os fatos no seu devido lugar. Sob a força da ditadura, Graciliano quer inserir, revolucionariamente, o ponto de vista dos vencidos na história dos vencedores, que leva da colonização ao estado moderno.

Sempre às vésperas de uma guerra, Bernardo Carvalho e Graciliano Ramos enfrentam a delicada relação entre presente e passado, verdade e mentira, documento e ficção, arte e política, no intrincado compromisso e contemporaneidade entre o estado totalitário, o marxismo o estruturalismo. Escritos de vidas, do outro e de si, que transbordam os gêneros textuais, as fronteiras espaciais e a cronologia temporal para narrar a história de uma modernidade autoritária e bélica, que se alimenta da exclusão do outro, a história de um estado disciplinador e unificador, que para triunfar deixa de lado o excesso, o múltiplo, o estranho, o indefinido, e se depara com a impossível definição do estrangeiro. $\mathrm{Na}$ tentativa de contrariar essa lógica, constroem-se estratégias distintas, maneiras de narrar. A pergunta sempre a mesma. A resposta sempre diferente.

A convivência e a simultaneidade entre Bernardo Carvalho e Graciliano Ramos, entre 1937 e 2001, é fabricada com a indecidibilidade que está no centro da natureza artística do cinema, matéria da crítica, da memória, matéria do romance, e da autobiografia, que atravessa os dois. Se a memória transita entre o passado e o presente, o real e o possível, se o cinema transita entre a passividade da máquina e a atividade do sujeito, fragmentação e narrativa, a autobiografia, um gênero auto-reflexivo por excelência, circula por todos eles.Trata-se de uma escrita em que o objeto é o sujeito da escrita, em que o dentro se manifesta fora, em que o viajante sempre volta ao ponto de partida, em busca, como afirma Gusdorf, de uma coincidência e de uma unicidade impossível entre o homem que escreve e o homem que é descrito, nunca iguais e sempre em re-configuração.(GUSDORF, 1991, p. 22/23) Trata-se ainda, segundo esse filósofo que inicia a sua longa reflexão sobre a autobiografia no cárcere alemão durante a guerra, de uma tentativa de domesticar o selvagem, o dentro, a memória, aquilo que é da ordem da incoerência, do informe e da inconsistência, aquilo que desafia a forma e a fórmula do fora, do espaço geométrico e do tempo linear. (GUSDORF, 1991, p.30/31)

A simultaneidade tensa, característica da literatura e condição da história, é também o segredo que herdamos dos nossos melhores ensaios de interpretação nacional: a idéia de "um passado que se estuda tocando em nervos"(FREYRE, 2002), a sensação de inadequação dos "desterrados na própria terra"(HOLANDA, 2002), a descoberta de que é possível "assistir pessoalmente às cenas mais vivas do seu passado"(PRADO Jr., 2002).

Reivindicar uma simultaneidade e uma convivência entre os opostos não significa reivindicar uma indistinção, muito pelo contrário. Como ensina Virno, o que provoca a indistinção entre presente e passado, real e virtual, e paralisa a história, não é a simultaneidade, mas justamente o ultrapassamento da fronteira que dá a um a aparência do outro, apagando a diferença no esforço de sincronização e justamente o ultrap

Sabendo que nenhuma tradição dura sozinha e que toda fragmentação é contrariada pela linearidade de um relato, a fabricação de uma convivência que nunca existiu, a montagem de fragmentos inatuais, inoperantes e esquecidos em outro contexto, a construção de um artifício que coloca em simultaneidade o não-simultâneo devolvendo-Ihe atrito, busca aprender a viver com o outro, aprender a dialogar com quem pensou o problema antes de nós e diante de nós, e a ensaiar uma política da memória e das gerações que não apague a diferença, mas que busque manter e provocar uma convivência tensa entre presente e passado, entre real e possível.

\section{Referências}

ANTELO, Raul. Literatura em revista. São Paulo: Ática, 1984

CARVALHO, Bernardo. Nove noites. São Paulo: Companhia das Letras, 2002.

D'ARAU O, Maria Celina O Estado Novo. Rio de Janeiro: J orge Zahar, 2000.

FREYRE, Gilberto. "Prefácio à primeira edição". In: Casa-grande \& Senzala: formação da família brasileira sob o regime de economia patriarcal. . SANTIAGO, S. (Coord.). Intérpretes do Brasil. Rio de Janeiro: Ed. Nova Aguillar, 2002. (V.II)

GUSDORF, Georges. Les écritures du moi. Paris: Éditions Odile Jacob, 1991

HOLANDA, Sérgio Buarque de. "Fronteiras da Europa". In. Raízes do Brasil. SANTIAGO, S. (Coord.). Intérpretes do Brasil. Rio de Janeiro: Ed. Nova Aguillar, 2002. (V. III)

LÉVI-STRAUSS, Claude. Partida. In: Tristes trópicos. Trad. Rosa Freire d'Aguiar. São Paulo: Companhia das Letras, 1996, p.15.

.História e Etnologia". In: Antropologia estrutural. Trad. Chaim Samuel Katz e Eginardo Pires. Rio de Janeiro: Tempo

MOLLOY, Sylvia. Vale o escrito: a escrita autobiográfica na América hispânica.Trad. Antonio Carlos Santos. Chapecó: Argos, 2003.

PRADO Jr, Caio. "Introdução". In: Formação do Brasil contemporâneo. SANTIAGO, S. (Coord.). Intérpretes do Brasil. Rio de Janeiro: Ed. Nova Aguillar, 2002. (V. III)

VIRNO, Paolo. El recuerdo do presente: ensayo sobre el tiempo histórico. Trad. Eduardo Sadier. Buenos Aires: Paidos, 2003.

RAMOS, Graciliano. "Uma tradução de Pero Vaz". In: Linhas tortas. 14 ed. São Paulo: Record, 1989.

RAMOS, Fernão e MIRANDA, Luís Felipe (Orgs.). Enciclopédia do Cinema Brasileiro. São Paulo: Ed. Senac São Paulo, 2000. 
Title: The Fabrication of a Coexistence

Author: Renata Telles

Abstract: A reading of Bernando Carvalho's narrative "Nove noites" and of Graciliano Ramos' critique of the film "Descobrimento do Brasil", by director Humberto Mauro, making possible for the author to design the relations between the State, art and intellectuals of the 1930s, between culture and society, between time and history, past and present, history and literature, with the goal of rehearsing a politics of memory and of generations, which does note erase difference, but which tries to keep and incites a tense coexistence between past and present, between the real and the possible.

Keywords: literature; literary theory; culture.

Titre: La Fabrication d'une fréquentation

Auteur: Renata Telles

Résumé: La lecture du récit Neuf Nuits, de Bernardo Carvalho, et de la critique que Graciliano Ramos fait du film Découverte du Brésil, de Humberto Carvalho, permettent à l'auteur dessiner les relations entre État, art et les intelectuels des années 30, entre culture et société, entre temps et histoire, passé et présent, histoire et littérature avec l'objectif de pratiquer une politique de la mémoire et des générations qui

n'effacent pas la différence, mas qui cherchent à maintenir et provoquer une fréquentation tendue entre présent et passé, entre réel et faisable. Mots-clés: littérature, théorie littéraire, culture.

Título: A fabricação de uma convivência

Autor: Renata Telles

Resumen: La lectura de la narrativa Nove Noites de Bernardo Carvalho y de la crítica que hace Graciliano Ramos a la película Descobrimento do Brasil de Humberto Mauro permite a la autora esbozar las relaciones entre Estado, arte e intelectuales en los años 30, entre cultura y sociedad, entre tiempo e historia, pasado y presente, historia y literatura con el objectivo de ensayar una política de la memoria y de las generaciones la cual no borre la diferencia sino que intente mantener y provocar una convivencia tensa entre presente y pasado, entre real y posible. Palabras-clave: Literatura; Teoria literaria; Cultura.

[1] RAMOS, Graciliano. Uma tradução de Pero Vaz. Linhas Tortas.(14ed.) São Paulo: Record, 1989. [Obs: Linhas tortas é uma publicação póstuma, 1962, e reúne crônicas publicadas em jornal por Graciliano entre 1915 e 1952. Trata-se de uma edição descuidada, sem prefácio sem apresentação, sem notas. Na primeira parte, composta de "Linhas tortas" e "Traços a esmo", aparecem as crônicas de 1915 a 1921 publicadas em Jornal de Alagoas, Paraíba do Sul e O índio. Na segunda parte, sem título, aparece uma série de textos que vão de 1935 a 1952, na qual poucos são datados e nenhum traz indicação de procedência. "Uma tradução de Pero Vaz" é publicada entre um artigo com data de abril de 1937 e outro de maio de 1937.]

[2] Os conflitos e compromissos do escritor com o estado totalitário são minuciosamente analisados, através de sua colaboração na revista Cultura e Política, de 1941 a 1944, em ANTELO, Raul. Literatura em revista. São Paulo: Editora Ática, 1984.

Renata Telles é doutora em Literatura pela Universidade Federal de Santa Catarina e pesquisadora do Núcleo de Estudos Literários e Culturais (NELIC) da mesma instituição.

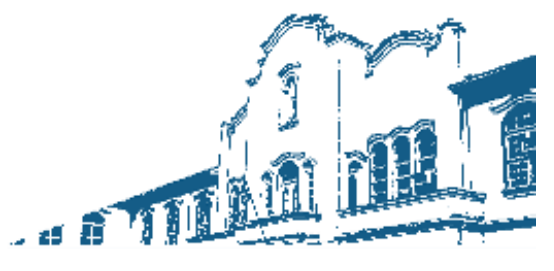

Copyright PPGCL/ Unisul 2006 @ (48) 3621-3369 - Desenvolvimento: Prof. Dr. Fábio J osé Rauen 